\title{
Empirical Model Analysis: The Effect of Management Ownership on The Use Of Free Cash Flows
}

\author{
R. S. Budi Suharto ${ }^{1}$, Donny T.S. Junias ${ }^{1}$, Meyulinda A. Elim ${ }^{1}$ \\ \{budisuharto73@gmail.com, tsjdonny@gmail.com, meyulinda.aviana@gmail.com\} \\ Politeknik Negeri Kupang ${ }^{1}$
}

\begin{abstract}
Research on the role of ownership is still an important debate in relation to the company's strategic policies. This relates to important decision making regarding the use of funds for operational and funding / investment purposes. Likewise, free cash flow where there are pros and cons in using it to increase company value. This debate is due to differences in the interests of each individual in management. The first hypothesis testing results proved that managerial ownership by the board of commissioners and directors tends to reduce the use of free cash flow for unprofitable activities. This research also proves the managerial role in utilizing free cash flow for investment purposes very well. The second hypothesis testing shows a significant coefficient value and is able to explain that the existence of managerial ownership will be able to increase the value of the company through investment activities sourced from free cash flow.
\end{abstract}

Keywords: managerial ownership, free cash flow, agency theory, effective monitoring hypothesis

\section{Introduction}

Different views regarding the role of ownership result in the absence of clear certainty about the role of ownership structure itself in the corporate environment. The amount of ownership can determine the extent of their role in determining the success of the company. Research on the role of ownership is also still an important debate in relation to the company's strategic policies. This relates to important decision making regarding the use of funds for operational and funding/investment purposes. Likewise, free cash flow where there are pros and cons in using it to increase company value. This debate is due to differences in the interests of each individual in management. These basic arguments and empirical facts are expected to produce new insights that are quite relevant in addressing agency problems, both those that occur internationally and nationally.

The phenomenon or empirical facts above certainly raises problems or big questions about the extent of the influence of management ownership on investment activities sourced from internal free cash flow. Therefore, based on these big questions, the purpose of this study is to examine the effect of company ownership on free cash flow. This test is conducted to find out how much the role of company ownership is related to the use of free cash flow funds (idle cash) to achieve the company's strategic objectives.

The urgency of this research is the need for further analysis in measuring how important the role of company ownership is in efforts to increase company value through investment activities that are right for the company. This is intended to at least provide an alternative 
discourse on the use of ownership factors to reduce agency problems related to free cash flow through management supervision and control activities.

The amount of share ownership will also determine the extent of their role in determining the success of the company (Mahadwartha [1]; Junias [2]; Junias [3]). Junias's research results [3] show the consistency of effective monitoring theory where the supervisory role of managers who have an ownership stake in the company has an impact on improving the performance or value of the company. The managerial ownership mechanism is an important element and a key factor in managing a company. Managerial ownership in the company will reduce the motivation of abuse of authority by the managerial. Equal position and interest in share ownership causes managerial parties to continue to work to improve company performance. High performance will bring a high level of investment, and a high level of investment brings maximum use of funding sources which will in turn increase the company's profit.

The relationship of cash flow and corporate investment expenditure is still widely studied, some of the causes are asymmetric information, long-term profitability factors, earnings management practices and also overinvestment in activities that harm the company (Pellicani and Kalatzis [4]; Razizadeh \& Talebnia [5] ). Increased investment is highly dependent on internal spending. Management's decision regarding investment behavior related to cash flow sensitivity is due to agency problems with the cash flow itself and asymmetric information in the capital market. The results of the study by Pellicani and Kalatzis [4] explain that management ownership rights have a very large influence on investment behavior on free cash flow owned by the company so that majority ownership tends to be dominant in investment decisions, especially if investment expenditure is sourced from internal funds.

The free cash flow hypothesis from the agency costs theory by Jensen and Meckling in Ding \& Qian [6] shows that managers with sufficient free cash flow will have a strong tendency to make expenses that are not beneficial to the company. Ding \& Qian [6] explained that the sensitivity of cash flow tends to cause over-investment activities rather than underinvestment depending on the type of ownership. The sensitivity of free cash flow in investment activities can lead to cost of agency caused by overinvestment behavior due to the dominance of ownership, especially government ownership, while underinvestment behavior tends to occur in foreign or private companies.

\section{Methodology}

The analysis method uses quantitative methods with analysis tools using regression analysis with the help of SPSS applications. The research data uses secondary data obtained from financial statements published and listed on the Indonesia Stock Exchange. Data collection techniques sourced by downloading from the Indonesia Stock Exchange website [7]. The data sample uses a purposive sampling method for banking companies in Indonesia in 2018 with the criteria of banking companies that are published at IDX and have managerial ownership. Investment activities use the Return on Assets proxy, free cash flow model uses the cash for operation less the cash for investment, and managerial ownership uses the share ownership proxy by the board of commissioners and directors. The empirical model of research used:

$$
\begin{gathered}
\text { FCF }=a+b \text { OWNS }+e \\
\text { INV }=a+b \text { OWNS } * \text { FCF }+e
\end{gathered}
$$


Note $: \mathrm{a}=$ constant $; \mathrm{b}=$ regression coefficients $; \mathrm{FCF}=$ free cash flow $;$ OWNS = managerial ownership $;$ $\mathrm{INV}=$ investment from free cash flow; $\mathrm{e}=$ error .

\section{Results and discussion}

The results of this study indicate that managerial ownership by the board of commissioners and directors tends to reduce the use of free cash flow. This is because they consider that the company they manage is also an important part of their daily activities. The sense of belonging to the company will certainly have an impact on the desire to be able to participate in the success of the company. Equal position and interest in share ownership causes managerial parties to continue to work to improve company performance.

Table 1.Regression Analysis Test for Hypothesis (1)

\begin{tabular}{|l|r|}
\hline \multicolumn{2}{|l|}{$F C F=a+b O W N S+e$} \\
\hline Constant & 1881,216 \\
\hline Coefficients & $-1436,265$ \\
\hline t-value / Sign test & $-0,120 / 0,906$ \\
\hline F-test / Sign test & $0,014 / 0,906$ \\
\hline R square & 0,001 \\
\hline Normality test (K-S test) & 0,190 \\
\hline
\end{tabular}

Table 1 shows the negative but not significant coefficient, meaning that even though their managerial ownership level is small, they are able to reduce the use of free cash flow for unprofitable activities, meaning that they tend to use their authority to focus more on improving the quality and performance of the companies where they work. Thus, if the company makes a profit, of course it will also have an impact on their well-being. This research is able to develop the assumptions and theories of effective monitoring in previous research by Junias [3] which states that managerial ownership is able to reduce the abuse of the authority of company management for the advancement of company performance. Although the amount of managerial ownership is relatively small, however, they play their supervisory role and still have the desire to participate in developing their company.

High performance will bring a high level of investment, and a high level of investment brings maximum use of funding sources which will in turn increase the company's profit. Increased investment is highly dependent on internal expenditure [4]. Management ownership rights have a very large influence on investment behavior on free cash flow owned by the company.

Table 2.Regression Analysis Test for Hypothesis (2)

\begin{tabular}{|l|r|}
\hline \multicolumn{2}{|l|}{$I N V=a+b O W N{ }^{*} F C F+e$} \\
\hline Constant & 2,049 \\
\hline Coefficients & 0,001 \\
\hline t-value / Sign test & $2,597 / 0,022$ \\
\hline F-test / Sign test & $6,744 / 0,022$ \\
\hline R square & 0,342 \\
\hline Normality test (K-S test) & 0,987 \\
\hline
\end{tabular}


Table 2 shows that the managerial role in utilizing free cash flow for investment purposes is very good. Significant coefficient value is able to explain that the existence of managerial ownership will be able to increase the value of the company through investment activities. This emphasizes that the managerial role is very important in managing the company. They will continue to strive to improve performance because ownership of shares which shows their ownership of the company so that they will continue to work to maximize their ownership role. Thus the results of this study support the research of Pellicani and Kalatzis [4] which revealed that management ownership rights have a very large influence on investment behavior on free cash flow owned by the company.

\section{Conclusion}

This empirical research proves that although their managerial ownership level is small, it is able to reduce the use of free cash flow for unprofitable activities, meaning that they tend to use their authority to focus more on improving the quality and oversight of company performance. This research is able to develop effective monitoring assumptions and theories regarding managerial roles in utilizing free cash flow for excellent investment purposes. The existence of managerial ownership will be able to increase the value of the company through profitable investment activities.

\section{Acknowledgements}

The authors would like to thank Politeknik Negeri Kupang for the financial support through the RUTIN Research programs.

\section{References}

[1] Mahadwartha, P. A. : Conflict Of Interest On Ownweship Versus Free Cash Flow: Dividend Policy Effectiveness, Journal of Indonesian Economy and Business Vol. 22 no.4 (2007)

[2] Junias, D. T. S. : Aliran Kas Bebas dan Nilai Perusahaan: Kajian pada Pasar Modal Indonesia, Jurnal MITRA, Politeknik Negeri Kupang, Vol. 19 No. 2, pp 210-217 (2012)

[3] Junias, D. T. S. : Struktur Kepemilikan dan Upaya Penyelesaian Permasalahan Keagenan Aliran Kas Bebas, Journal of Science and Engineering-Media Exacta Universitas Nusa Cendana, Vol. 15 No. 1 (2014)

[4] Pellicani, A., D., \& Kalatzis, A. E. G. : Ownership Structure, Agency Problems of Free Cash Flow and Asymmetric Information: Evidence from Brazil, website : http://sbfin.org.br/encontros-anteriores-assets/2014/artigos/ID4545, (2014)

[5] Razizadeh, R., \& Talebnia, G. : The Effect of Managerial Ownweship On Relationship Between Free Cash Flow and Earning Managemnet, Medwll Journals-The Social Sciences Vol. 11 (9) (2016)

[6] Ding Y. \& Qian X.: Investment Cash Flow Sensitivity and Effect of Managers' Ownership: Difference between Central Owned and Private Owned Companies in China, International Journal of Economics and Financial Issues Vol. 4, No. 3, pp.449-456, (2014)

[7] Indonesia Stock Exchange: Annually Financial Report - Banking Sector, https://www.idx.co.id/perusahaan-tercatat/laporan-keuangan-dan-tahunan/, (2018) 